\author{
Paulina Topolska
}

\title{
The Development of the American Private Sector in Relation to International Law. From the First Artificial Satellite to The American Space Commerce Free Enterprise Act
}

\begin{abstract}
Introduction
On October 4, 1957, the Soviet Union launched the first artificial satellite. This started the space era. It was said that the process of exploring the cosmos was inevitable as it was the next stage of the development of civilization. For many years, humanity had been preparing for this very moment, not only in terms of scientific and technological achievements, but also due to the requirements of the law of nature. ${ }^{1}$ This global initiative quickly found its reflection in international agreements regulating the issues of the study and exploration of outer space. The beginning of the space exploration era brought enormous benefits to humanity at the time when international law was becoming universal. ${ }^{2}$ At the beginning, the only actors taking part in the exploration were the bodies referred to in the convention, i.e. states. However, over time, the private sector joined space exploration in spite of the fact that no particular international regulations applied to private bodies.
\end{abstract}

\section{The Beginning of Commercialization}

The commercialization and privatization of the space industry commenced in the 1980s, with the activities of the United States of America. This increasing cooperation of states with the private sector was triggered by the evolving global commercialization related to space activities, technological development and high costs that could

1 A. Blagonravov, Christian Science Monitor, 1967, quoted from: M. Lachs, The Law of Outer Space. An Experience in Contemporary Law-Making, A.W.Sijthoff International Publishing Company, Leiden 1972, p. 4.

2 M. Lachs, The Law of Outer Space. An Experience in Contemporary Law-Making, A. W. Sijthoff International Publishing Company, Leiden 1972, p. 14. 
not be afforded by the states. ${ }^{3}$ Nonetheless, such cooperation entails the responsibility of the states to provide continuous supervision over the private sector, as according to the Outer Space Treaty of 1957 only states shall be responsible for damages caused by space objects.

The commercialization process in the USA began in 1965, as Early Birth - the first commercial satellite, was launched into space. ${ }^{4}$ Since then, the private sector has gradually expanded its participation in space activities. Perhaps it is not a widely known fact that the famous spacecraft from NASA Apollo mission, which enabled the first human landing on the moon, was designed and constructed by private enterprise. ${ }^{5} \mathrm{~A}$ significant precedent was the establishment of a Communication Satellite Corporation (COMSAT) in the USA, which comprised both states and private companies. It should be noted that the United States was the only Western country, which provided the service of putting objects into space.

The situation changed when the European Space Agency began to develop in Europe. In the years 1963-1982, more and more private manufacturers of space vehicles were set up in the USA. The US President at the time, Ronald Regan, ran a policy supporting the private space sector, encouraging private enterprises by creating long-term government plans. ${ }^{6}$ In 1982, after the first successful private launch into space, he issued an order "National Space Policy" on national security, in which he stated that the expansion of the private sector became a national goal. On May 16 1983, the President issued another act regarding the commercialization of the expansion of space vehicles, in which he stated that the government would fully support and facilitate the commercialization of space vehicles. In addition, the document contained a statement that the US government would license, supervise or regulate commercial operations in the United States solely to the extent required to meet its domestic and international obligations and to ensure public safety. The wording of the act ensured the act was not considered contrary to international law. In 1984, the US Congress adopted the vital legislation of the National Aeronautics and Space Act. The legislation covered three substantive areas: licensing and regulations, introducing requirements of civil liability insurance and access of private companies to state facilities. ${ }^{7}$ In the early years private enterprises focused on telecommunication services and the construction of space facilities. The next area private entrepreneurs were allowed to expand to was launching objects into space. They obtained permission to build and launch cargo space systems and service them in NASA space

3 L. Eukaszuk, Wspótpraca i rywalizacja w przestrzeni kosmicznej. Prawo, Polityka, Gospodarka, Dom Organizatora, Torun, 2012, p. 302.

4 A. Velocci, Commercialization in Space, Harvard International Review, 2012, http://hir.harvard. edu [access: 6.09.2017].

5 Ibidem.

6 L. Eukaszuk, op. cit., p. 309.

7 https://www.faa.gov/.../history/.../Commercial_Space_Industry.pdf [access: 6.09.2017]. 
centres. ${ }^{8}$ In the following years, the private sector focused on the construction of a reusable space vehicle and the production and processing of objects on research facilities in space. For more efficient management of private projects, NASA has created an additional department to coordinate private sector activities. The United States, through the involvement of the private entities, has undoubtedly gained many benefits, although it should be mentioned that the profits were mutual. Private entrepreneurs gained financial profits and the public sector could boost its technological development. ${ }^{9}$

Currently, the key commercial use in the space sector can be found in telecommunications, the financial markets and many other important sectors. However, the current activities of the private sector are heading towards a completely different model. This is due to the growing number of enterprises involved in the conquest of outer space. The international community has entered the process of re-evaluating existing sources regulating activities in space. Anthony Velocci in his article "Commercialization in Space" for the Harvard International Review suggests that we are entering a "new era of commercial space". In 2012, he argued that in the next decade the sceptics would be witnessing the new aspects in commercial space. ${ }^{10}$ It must be said that he was right, as evidenced by the latest draft of the American Space Commerce Free Enterprise Act of 2017.

It can be considered that this act is the result of continuous efforts of the private sector. The technological level has reached the point at which the act can be adapted to commercial ventures. The private sector can also be proud of the knowledge gained during decades of cooperation with the government. However, before we proceed to the analysis of the latest US bill, let us focus on the two aspects that prove the necessity of a new reform.

\section{Why Reform for the Private Sector was Necessary}

In the United States, it is said that the Act aims to fulfil the earlier unregulated area of the space private sector, both in terms of current operations and potential future missions. It is a great step that aims to regulate issues associated with the American commercial space industry and opens the door for new space missions.

With the development of satellite remote sensing, considerations of its privatization started to develop. The fiasco of the development efforts in the 1970s and 1980s led to a belief that remote sensing was a public good, and the private sector could not obtain any benefits from its development. As a result of the private sector's undervaluation, the archaic remote sensing regime became too onerous. The current restrictions that

8 L. Łukaszuk, op. cit., p. 310.

9 Ibidem.

10 A. Velocci, Commercialization in Space, Harvard International Review, 2012. 
limit the implementation to only existing methods and create barriers for entrepreneurs are ineffective and very unfavourable for the United States and the global space economy.

The second aspect is the difficulty related to the lack of principles regulating new space missions involving the private sector. Currently, the activities of private entities in space, such as suborbital flights, mining raw materials from asteroids, sending rovers to Mars, are not subject to any supervisory authority. To this point, no act has regulated these space activities, which raises the concerns of space entrepreneurs. These circumstances put the private sector in an uncomfortable and unsafe position that may impede new initiatives and technological and economic development. The status quo may entail United States losing share in a global space market to other countries that have such regulations. ${ }^{11}$

\section{The American Space Commerce Free Enterprise Act and International Law}

The Treaty on Principles Governing the Activities of States in the Exploration and Use of Outer Space, including the Moon and Other Celestial Bodies, also known as the Outer Space Treaty, was signed on January 27 1967. It is a kind of constitution for one hundred signatory states. This document contains a set of rules that should guide countries operating in space. These are:

1) Exploration and use of outer space, including the Moon and other celestial bodies, should be carried out without obtaining property benefits and in the interest of all humanity.

2) Space is free for exploration and use for all states without any discrimination, on the basis of equality and in accordance with international law.

3) Space shall not be subject to appropriation either by proclaiming sovereignty, by means of use or occupation, or by any other means.

4) States Parties to the Agreement shall operate in the field of research and use of outer space, in accordance with international law, including the United Nations Charter, in the interest of maintaining international peace and security and developing cooperation and understanding between Parties.

5) States Parties to the Agreement undertake not to put into orbit any nuclear or any other type of weapons of mass destruction or place such weapons on celestial bodies.

11 J. Hampson, The American Space Commerce Free Enterprise Act, https://niskanencenter.org [access: 11.09.2017]. 
6) The Moon and other celestial bodies shall be used by all States Parties to the Agreement solely for peaceful purposes.

7) By using space, States Parties shall be guided by the principles of cooperation and mutual assistance.

8) Astronauts are considered to be messengers of humanity. Each State Party undertakes to assist in the event of an accident, danger or forced landing on its territory.

9) Each State Party bears international responsibility for its activities in outer space, whether it is carried out by governmental or non-governmental institutions, legal entities, and ensures that such activities are compatible with the provisions of the Agreement.

10) Each State Party shall have jurisdiction and control over their facilities and personnel launched into space.

11) States undertake to conduct consultations before unsafe operations in space and to inform the Secretary-General of the United Nations of their activities.

12) Space stations and other installations located on the Moon and other celestial bodies shall be available to all States Parties to the Agreement. ${ }^{12}$

Analysing these fundamental principles of the Treaty, we may notice that space has been recognized by international law as res communis, used for peaceful purposes and in the interest of the humanity. It should be considered whether the status of outer space (communis omnium) is regulated by the aforementioned Treaty or by customary law. To give an answer, a few examples shall be analysed. At the Hamburg Conference in 1960, the International Law Association adopted a resolution on the space regime in which Art. 3 states that: "outer space may not be subject to the sovereignty or other exclusive rights of any State." 13 The commonly cited project of the Code of the David Davies Memorial Institute from 1962 decides: "outer space, including the Moon and other celestial bodies is a res communis omnium, i.e. an area open for free exploration and use by all States which is not subject to national appropriation". ${ }^{14}$ Similar regulations can be found in the provisions of the Interamerican Bar Association or the Space Law Committee in Hungary. The status of outer space has also been repeatedly discussed in the preambles of the United Nations Resolution. Resolution A Res. Well. 1721 / XVI - Dec. 20th, 1961 states that according to international law, space and celestial bodies are free from exploration and use by states and are not subject to appropriation. ${ }^{15}$ What is more, Resolution

12 Dz.U. no. 14 , item 82.

13 Report of the Forty-Ninth Conference - Held at Hamburg, August 8th to August 12th, 1960, p. 267.

14 David Davies Mameorial Institute, Draft Code of Rules on the Exploration and Uses of Outer Space, 1963, 29 J. Air L. And Comm. p. 141.

15 Resolution Adopted By The General Assembly1721 (Xvi). International Co-Operation In The Peaceful Uses OfOuter Space. 
A Res. Well. 1962 / XVIII mentions that space and celestial bodies are not subject to appropriation, occupation or other similar activities. ${ }^{16}$ All of these examples indicate that space law is not just a postulate or a theory, but beyond the Space Treaty it develops directly from customary law.

The international arena considered the views of scientists that developed concepts variety of concepts, i.e. introducing the notions of res communis humanitatis saying that space belongs to all humanity, res communis civium that space is the property of all people residing in the earth, res communis omnium universi, which treats space as the common property of all intelligent beings in the universe or res extra commercium, which entails that space cannot be treated as a subject of state supremacy. ${ }^{17} 18$

Space, morally speaking, is the property of all humanity, as the Treaty establishes laws for all states without any discrimination, based on considerations of equity. ${ }^{19}$ Furthermore, it shall be noticed that in the light of the Treaty, humanity (communis) are the states. However, the entire space law system also relates to private entities. International law, in addition to major bodies such as states or international organizations, refers in some assumptions directly to individuals / citizens. As Gyula Gal observed in his book "Space Law", "Since res communis humanitatis (space law as the law of humanity) ${ }^{20}$ and res communis civium (space law regarded as co-ownership law also addressed to individuals) ${ }^{21}$ refers to citizens on the basis of international law it should be stated that space is the property of the res communis civium."22

The draft of the The American Space Commerce Free Enterprise Act and International Law contains many controversial solutions. It is said that it may conflict with in-

16 Resolution adopted by the General Assembly 1962 (XVIII). Declaration of Legal Principles Governing the Activities of States in the Exploration and Use of Outer Space.

17 A. Górbiel, op. cit., p. 56.

18 Cf. A. A. Cocca, Determination of the Meaning of the Expression Res Communis Humanitatis in Space Law, Sixth Colloquium on the Law of Outer Space, IISL, Paris 1963, pp. 3-4, E. Scifoni, The Principle of Res Communis Omnium and Peaceful Use of Space and of Celestial Bodies, Seventh Colloquium on the Law Outer Space, IISL, Warszawa 1964, p. 50, H. Valladao, The Law of Interplanetary Space, Second Colloquium on the Law of Outer Space, IISL, London 1959, p. 163-164, C. Berezowski, Międzynarodowe prawo lotnicze, Warszawa 1964, pp. 83-84, M. Niciu, Umele consideratil cu privire statul juridic al. Corpurilar cersti, Studia Universitatis Babes-Bolyai, Seres Iurisprudentia 1965, p. 58, C. W. Jenks, International Law and Activities in Space, in: "The International and Comparative Law Quarterly", vol. 5, section. 1, p. 104, B.Cheng, The 1967 Space Treaty, in: "Journal de Droit International", vol. 95, 1968, p. 564, D. J. L Brownlie, Public International Law, London 1970, p. 295.

19 G. Gal, Space Law, A.W.Sijthoff-Leyden, New York 1969, p. 123.

20 A. A. Cocca, Determination of the Meaning of the Expression Res Communis Humanitatis in Space Law, Sixth Coll, 1963, p.2, cited from: G. Gal, op. cit., p. 125.

21 E. Scifoni: The Principle Res Communis Omnium and Peaceful Use of Space and Celestial Bodies, Seventh Coll, 1964, p.50, cited from: G. Gal, op. cit., p. 123.

22 G. Gal, op. cit., p. 123. 
ternational law and thus allow the United States and its citizens to excessively interfere in space.

The first notable assumption is the provision which states that "the US citizens and entrepreneurs have the right to explore and use space, including the use of its resources without any conditions or limitations." ${ }^{23}$ The Americans explain that the private interest of each citizen is a privilege granted by the executive power. A private interest is often subject to the law with the reservation that it is a subject to the supervision of the authority that grants it. Of course, citizens cannot be deprived of their rights without appropriate procedure and the same applies to private interests in conducting business in outer space. Further articles of the Act provide two possibilities on how to limit this activity. According to the Act, freedom of exploration and use of space by entities, either citizens or entrepreneurs registered in the United States, may be limited by two exceptions: security considerations of the United States and obligations resulting from the already discussed Space Treaty. ${ }^{24}$ It should be noticed that Art. 6 of the Treaty provides that "Activities of non-governmental legal entities in outer space, including the Moon and other celestial bodies, requires authorization and continuous supervision by the relevant State Party to the Agreement". ${ }^{25}$ The term "requires" creates a legal obligation to grant permits and provide continuous supervision over private activities in space. Therefore, this article does not imply that the United States is forced to authorize private space activities, but allows the establishment of private enterprises operating in outer space in the state, provided that the state constantly supervises private enterprises and be responsible for them on the international scene.

The draft of the US bill introduces a reduction of administration requirements related to supervision and issuing permits to operate in space, with all the regulations of state supervision over private facilities being preserved. The bill introduces a condition that private entities willing to be active in space shall obtain the appropriate certificate, which will be issued by the Secretary of the Office of Space Commerce.

To receive a certificate, the applicant will have to fulfil numerous requirements, including the requirements of size of the space object, the type of actions to be undertaken, its duration, location and the potential deorbitation method. In addition to these conditions, each applicant will be required to submit a space insurance agreement with a declaration that the object is not a nuclear weapon or a weapon of mass destruction, is not designed to bring the above into orbit, will not undertake any tests of nuclear weapons, and all the provided information is truthful, complete and accurate. ${ }^{26}$ However, the ques-

23 American Space Commerce Free Enterprise Act of 2017, § 8011, sec 4 (b).

24 K. Muzyka, Komentarz do Projektu American Space Commerce Free Enterprise Act of 2017, https://prawoikosmos.wordpress.com, [accsess: 6.09.2017].

25 Dz.U. no. 14, item 82.

26 American Space Commerce Free Enterprise Act of 2017, § 8010. 
tion arises of whether a space object that is towing an asteroid can be treated as a weapon of mass destruction. Such considerations were undertaken by Dandrige M. Cole who, during the annual meeting of the American Astronauts Society in 1962, gave the speech: "A Possible Military Application of a Cis-Martian Asteroid". ${ }^{27}$

As part of state supervision, the act introduces the establishment of the Private Space Activity Advisory Committee. The main tasks of the Committee will include: the analysis of the status and development of non-governmental activities in space, the analysis of the efficiency and effectiveness of the certification process, issuing recommendations for the Secretary and Congress on ways to promote the development of the private sector, the evaluation of existing practices and wide support including recommendations and advice for private entities. ${ }^{28}$

\section{Literature}

Blagonravov A., Christian Science Monitor, 1967, quoted from: Lachs M., The Law of Outer Space. An Experience in Contemporary Law-Making, Leiden 1972.

Lachs M., The Law of Outer Space. An Experience in Contemporary Law-Making, Leiden 1972.

Eukaszuk L., Wspótpraca i rywalizacja w przestrzeni kosmicznej. Prawo, Polityka, Gospodarka, Torun 2012.

David Davies, Draft Code of Rules on the Exploration and Uses of Outer Space, J. Air L. And Comm.1963, no. 29.

Cocca A. A., Determination of the Meaning of the Expression Res Communis Humanitatis in Space Law, Sixth Colloquium on the Law of Outer Space, Paris 1963.

Scifoni E., The Principle of Res Communis Omnium and Peaceful Use of Space and of Celestial Bodies, Seventh Colloquium on the Law Outer Space, Warszawa 1964.

Valladao H., The Law of Interplanetary Space, Second Colloquium on the Law of Outer Space, London 1959.

Berezowski C., Międzynarodowe prawo lotnicze, Warszawa 1964.

Niciu M., Umele consideratil cu privire statul juridic al. Corpurilar cersti, Studia Universitatis Babes-Bolyai, Seres Iurisprudentia 1965.

Jenks C. W., International Law and Activities in Space, "The International and Comparative Law Quarterly", vol. 5, item 1.

Cheng B., The 1967 Space Treaty, "Journal de Droit International", vol. 95, 1968.

Brownlie D. J. L, Public International Law, London 1970.

Gal G., Space Law, A.W.Sijthoff-Leyden, New York 1969.

Dz.U. no. 14, item 82.

27 K. Muzyka, op. cit.

28 American Space Commerce Free Enterprise Act of 2017, § 80109. 
Resolution Adopted By The General Assembly1721 (Xvi). International Co-Operation In The Peaceful Uses OfOuter Space.

Resolution adopted by the General Assembly 1962 (XVIII). Declaration of Legal Principles Governing the Activities of States in the Exploration and Use of Outer Space.

American Space Commerce Free Enterprise Act of 2017, Dz.U. of 14, item 82.

Velocci A., Commercialization in Space, Harvard International Review 2012, http://hir. harvard.edu [access: 6.09.2017].

https://www.faa.gov/.../history/.../Commercial_Space_Industry.pdf

Hampson J., The American Space Commerce Free Enterprise Act, https://niskanencenter. org.

Muzyka K., Komentarz do Projektu American Space Commerce Free Enterprise Act of 2017, https://prawoikosmos.wordpress.com.

\section{SUMMARY}

\section{The Development of the American Private Sector in Relation to International Law. From the First Artificial Satellite to The American Space Commerce Free Enterprise Act}

The active development of technology enbled mankind to realize new programs for the exploration of previously inaccessible areas of the universe hundreds of thousands of kilometers away. The emergence of this new field created the need to ensure its special legal regulation, which would correspond to the specific characteristics of this business. But now we have entered into a phase of re-evaluation of existing legislation of space and we must realise that alongside countries operating in space an has arisen entirely new entity - the private sector. Therefore it is necessary to ask ourselves whether the privatization and commercialization of outer space is legally possible and if it is not precluded by existing treaties. The draft of the latest US Commercial Space Act is undoubtedly a great advance for key areas of the private sector activity such as remote sensing and new space missions. It provides a sense of confidence for entrepreneurs by strictly regulating issues related to the supervision of private sector entities. However, on the international scene the question has arisen of whether this act is contrary to international law, especially principles contained in existing space law treaties.

Keywords: public international law, space law, the American Space Commerce Free Enterprise Act

Paulina Topolska, University of Gdańsk, Faculty of Law and Administration, Bażyńskiego 6, 80-309 Gdańsk, e-mail: paulina.topolska@prawo.ug.edu.pl. 
